\title{
Pharmacist contributions for basic care from the perspective of professionals of familial health care teams
}

\author{
Gecioni Loch-Neckel ${ }^{1 *}$, Maria Aparecida Crepaldi ${ }^{1,2}$ \\ ${ }^{1}$ Center of Health Sciences, University of Santa Catarina, ${ }^{2}$ Department of Psychology, Center of Philosophy and Human \\ Sciences, Federal University of Santa Catarina
}

\begin{abstract}
This study aimed to investigate the social representations of professionals included in the team of Family Health Strategy (physicians, nurses and dentists) respecting the action possibilities and contributions of the pharmacist for the basic care, and based on social psychology and, particularly, on the theory of social representations. The epistemological basis of the research is qualitative, and the data were collected by means of individual semi-structured interviews, which were submitted to analysis of categorical thematic content. Apparently, the majority of professionals already inserted in the team know and recognize the importance of professional pharmacists in the basic care, as well as their potential contribution to this topic. The representations were constructed according to the following parameters: a) the study object and the intervention area, b) the individual practice of every professional and c) his/her action in specific cases. The quality of the professional or personal experience concerning the action of these professionals has contributed for the knowledge about the possibilities of pharmacists' intervention in basic care.
\end{abstract}

Uniterms: Pharmacist/action. Pharmaceutical intervention. Family Health. Pharmaceutical attention.

Este estudo teve por objetivo investigar as representações sociais dos profissionais incluídos na equipe de Estratégia em Saúde da Família (médico, enfermeiro e odontólogo), sobre as possibilidades de atuação e as contribuições do farmacêutico na atenção básica, tendo por fundamento a psicologia social e, particularmente, a teoria das representações sociais. A base epistemológica da pesquisa é qualitativa, sendo os dados coletados por meio de entrevistas individuais semi-estruturadas e analisados por meio de análise de conteúdo categorial temático. Constatou-se que a maioria dos profissionais já inseridos na equipe conhece e reconhece a importância do profissional farmacêutico na atenção básica e as suas possibilidades de contribuição. As representações foram construídas a partir dos seguintes parâmetros: a) o objeto de estudo e de intervenção da área; b) as práticas de cada um dos profissionais e c) a sua atuação em casos específicos. A qualidade da experiência profissional ou pessoal acerca da atuação desses profissionais contribuiu para o conhecimento sobre as possibilidades de intervenção do farmacêutico na atenção básica.

Unitermos: Farmacêutico/atuação. Intervenção farmacêutica. Saúde da Família. Atenção farmacêutica.

\section{INTRODUCTION}

The Family Health Strategy (Estratégia de Saúde da Familia - ESF) is constituted by a proposal for change the work process in basic care in Brazil, with the purpose to qualify the population health care based on guidelines from the Unified Health System and the fundamental principles of basic care: integrality, quality, equity and social participation.

\footnotetext{
*Correspondence: G. Loch-Neckel. Centro de Ciências da Saúde. Universidade Federal de Santa Catarina. Campus Universitário Trindade - 88040-900 - Florianópolis - SC, Brasil. E-mail: gneckel@hotmail.com
}

The Family Health teams are composed by physicians, nurses, nursing technicians and communitarian health agents (Brasil, 1997) and dentists (Brasil, 2000). The ESF was developed with the purpose to narrow the commitment ties between health, educational, and management professionals and the user population of health services. This initiative has presented important advancements in the services rendering, once it has been contributing significantly for the effectuation of a change in the assistance model, with emphasis in the family health promotion (Brasil, 1997).

The team work is mentioned in the conjunct of ESF 
characteristics, as one of the more important intents for the restructuration of work process and as a possibility of a more integral and decisive approach (Silva, Trad, 2005). The team is responsible for all aspects implied in health and has as purpose to share with the community the paths and decisions related to promotion, prevention and attendance to family health (Campos, 2003).

From the year of 2000 forward, some reformulations have been done in the composition of family health teams. The odontologist professional (dentist), together with a dental consulting room attendant, or a dental hygiene technician, passed to integrate the ESF team. Respecting to other professions, also in the year of 2000, the Ministry of Health published in an official document:

"Other health professionals, such as psychologists, dentists, physiotherapists, among others, shall be integrated to these basic units, according to demands and characteristics of local health services organization, and they shall be identified with this work proposal, which requires creativity and initiative for communitarian and team works." (Brasil, 2000).

From this document, also the Federal and Regional Councils of every professional category are organizing themselves and striving for the insertion of their professionals in the public health services, including the Family Health Strategy. This strife came in the bulge of Health Reformation and the creation of SUS (Sistema Único de Saúde or Unified Health System), in the form of an ample movement from the organized civil society, by means of participation in Health Conferences and changes in curricular frame of universities, among others.

The courses of Family Health professional formation in Brazil, in the form of specialization or residency have been constructed with multiprofessional character, including professionals such as social workers, pharmacists, psychologists, nutritionists, speech therapists and physiotherapists, among other. These courses are loci of important experiences for the development of an interdisciplinary practice, as this practice does not receive the necessary emphasis in the graduation courses. Besides, the programs stimulated by Ministry of Health, such as Multiprofessional Residencies and Specializations in Family Health, open space for new conquests in qualification of health care in Brazil. These courses have been created from the reorientation given by Ministry of Health, as well as the academic interest from graduation courses in health and health services themselves. The possibility of experience the work within a multiprofessional team, as well as the interdisciplinary practice, enables professionals for the assistance model change.

On March $28^{\text {th }}, 2006$, it was published the Ordinance 648/GM approving the National Policy of Basic Care, defined as: "conjunct of health actions, in the individual and collective ambits, which embrace the promotion and protection to health, the prevention of health exacerbations, diagnoses, treatments, rehabilitations and maintenance". So, it was defined that federal resources for the defrayment of health actions and services should be anticipated and destined in the budgets from the three spheres of management, having between its purposes to support initiatives for the qualification and formation of human resources addressed to Basic Care. Also in the year of 2006, the Ordinance 698/GM, published in a March edition of the "Union Official Daily Newspaper", has established funding blocs, among them the pharmaceutical care. This increase in the decentralization of financial resources of Ministry of Health and, mainly, in which is referred at Ordinance 698 , has aimed to invest in the organization and qualification of pharmaceutical care services in cities where these services were not available, and improve and organize them in cities where they were already established in any form, regulating so the development of basic care actions to health in the SUS.

The pharmaceutical care is a fundamental part of health care services rendered to citizens, aiming the health promotion, exacerbations prevention and recovery to patients, when the utilization of some type of medication is the main alternative. In these situations, the physician is the essential element for the increase of solvability of attendance to patient and for the effectiveness of health care process (Brasil, 2001). When talking about health promotion, quality of life, and intervention on the factors that put it under risk, it is not possible to lay aside a reflection about the medications issue, their respective relationship with user and environment, and consequently, in the pharmacist professional participating in this relationship and integrating the health team (Dalla Costa, 2000).

The efforts for pharmaceutical activities and practices readequacy aiming the rational use of medications, presupposes the professional action of pharmacist in a more effective way. In this sense, the conception of Pharmaceutical Care presented as follows, allows to complement the assistance to user in the multidisciplinary Family Health team:

"It is a model of pharmaceutical practice, developed in the context of Pharmaceutical Care and that comprehends, attitudes, ethical values, behaviors, abilities, commitments and 
co-responsibilities in the disease prevention, health promotion and recovery, in a form integrated to health team. It is the direct interaction of pharmacist with user, aiming a rational pharmacotherapy and obtainment of defined and measurable results, turned to improvement of quality of life. This interaction should also involve the conceptions of its subjects, respected their bio-psycho-social specificities, under the optics of integrality of health actions." (OPAS, 2002).

According to proposal for the qualification of Multiprofessional Residence in Health Family of UFSC (Da Ros et al., 2002), the activities that should be developed by the pharmacist in the ESF teams are: adequacy of pharmacies in Health Centers; evaluation of adequacy of existing medications in the Health Centers (term of validity, packages, physical-chemical conditions); planning, follow up, and evaluation of the program of implantation of phytotherapy in health care, of medicinal gardens in Health Centers, and of the popular use of medicinal plants; activities of medication dispensation, proceeding with the due prescription evaluation, medication delivery and corresponding orientation; documentation of the pharmacologic profile of attended clientele; recording in the customer medical history about aspects related to medicative therapy; visit to hospitalized patients for supervision of pharmacotherapy and; secondary attendance developing activities of medications management in the central level of municipal administration and follow up of activities in toxicological information centers.

Although there is acknowledgement of the importance of actions related to pharmaceutical care, the presence of pharmacist professional in public health services is small, face the actual necessities, considering that medication is an essential supply in the health care (Vieira, 2007).

In this line of approach, little is known about how the physicians, nurses and dentists perceive the pharmacist action in basic care, or integrating the Family Health team. Aiming to contribute to fill this gap in knowledge, this study had as purpose to investigate the social representations about the pharmacist from the professionals included in the ESF team, having as ground the social psychology and, particularly, the theory of social representations. We have studied herein the beliefs and opinions, from professionals included in the minimum team, about the pharmacist; that is, we pursued the characterization of pharmacist as object of social representation, for this groups of professionals.

\section{Theoretical Considerations}

\section{Social Representations}

The representations from the professionals already inserted in the Family Health teams about the pharmacist professional action in these teams will be approached by means of the Theory of Social Representations. The study of Social Representations arose in the field of Social Psychology with Serge Moscovici in the decade of 1960, as an alternative approach to traditional theories of social cognition. The social representations are exactly on the interface between the psychological and the social, and present themselves as a transformation activity between the scientific knowledge and the common sense.

The building of social representations of scientific theories or formalized professions, that is, the modifications they suffer as are arrogated by different social groups, should be considered from factors such as social condition, religious and political beliefs, and scholarship. The social representations are, therefore, a form of practical knowledge, or "social thinking", addressing aspects of communication, understanding, and domination of social, material and ideal environment (Jodelet, 1991). Considering that such representations orient these fundamental aspects in social interactions, it is possible to evidence the pertinence of use of such theoretic referential to investigate the perspective of professionals that, in a certain way, have their "place" already established in the public policies of basic care and ESF, respecting to health professionals for which such space is still being constructed as social practice.

The formation of health professionals contemplates the learning of theories and specific techniques from the action nucleus and respective field. The representations about the action of health professionals present differences respecting to specific positions, such as professionals - technical formation, secondary school, higher school - service users, managers, for instance. The information sources are important data for the comprehension of social representations building, and could be developed in different manners: access to available scientific knowledge, participation in multiprofessional courses, previous or current formal work relationships, and informal relationships of friendship or familial, with the referred professionals.

In this purpose, it is essential to know the representations that health professionals of the minimum Family Health team have about the pharmacist, to know if such professionals develop activities that would be attributed to pharmacist, and investigate the information sources from which they have obtained knowledge about the pharmacist action, in order to verify if, in practical terms, the Family 
Health Strategy is in accordance with the proposal of integral attendance of the Unified Health System user.

\section{METHOD}

Study Place: The research was developed in a city of Southern Brazil, into 7 Basic Health Units.

Participants: Higher education professionals have participated in this study, legally included in the ESF minimum team, that is, physicians, nurses and dentists.

Research characterization: This research is of descriptive-correlation type with epistemological qualitative base, pertinent to investigation of complex phenomena, such as representations, experiences, beliefs, values and meanings (Minayo, Sanches, 1993). The research was approved by the Institutional Review Board/Independent Ethics Committee of Federal University of Santa Catarina (Appraisal \# 297/2005) and was developed according to norms of Resolution 196/96 of National Health Council, and all participants were clarified about its objectives and method, by means of reading a Informed Consent Form that was further signed. The research did not present risks for its participants; secrecy was assured to then, as well as the return about its results.

Procedures for collection and analysis of data: The data were collected in the period between 2005 September and November, by means of individual semistructured interviews, recorded and transcribed for analysis. Every interview lasted an average of 30 to 60 minutes and investigated, between other themes, the professional experience and necessity of a pharmacist in the team, if users referred the pharmacist absence in the Units, and if interviewed people did know the pharmacist attributions. In the results analysis and discussion, the pieces of participant reports were identified as Interview 1, Interview 2, ..., Interview 15.

The collected data were analyzed according to thematic categorial analyses of content (Bardin, 1977), which allowed to identify a posteriori the categories of analysis, as a function of generalities and peculiarities found in the participant reports.

\section{RESULTS AND DISCUSSION}

\section{PROFILE OF INTERVIEWED PROFESSIONALS}

Table I shows the characterization of research participants respecting to age, gender, formation area, specialization and time of professional action. Out of the interviewed professionals (15), 67\% were of female gender, $46.7 \%$ were physicians, $33.3 \%$ nurses and $20 \%$ dentists.
The majority of interviewed people had some formation in the Public Health area (53.3\%), being that some professionals had concluded more than one specialization (20\%). Only 3 interviewed professionals had only their graduation as professional formation. The age of interviewed people varied from 23 to 60 years, being that $40 \%$ of them were up to 30 years old. The time of action and participation in current Family Health team varied fairly: $26.6 \%$ were in the team for less than 6 months, $46.8 \%$ acted in the same team for a period of 1 to 2 years, while $26.6 \%$ acted during a interval of 3 to 5 years. Two medical professionals reported to work with communitarian health since their graduation (22 and 26 years of profession).

TABLE I - Characterization of research participants

DATA OF PARTICIPANTS $n$

\section{Professional Categories}

Physician $\quad 7$

Nurse $\quad 5$

Dentist

Post-Graduated

Specialization in Public Health 8

Specialization in Other Areas $\quad 7$

Graduation Only 3

Age

Up to 30 years 6

From 31 to 50 years 5

Above 51 years 4

Gender

Male 5

Female 10

Time of Professional Action

Up tol year 1

From 1 year to 10 years 7

From 11 years to 20 years 1

From 21 years to 30 years 6

Time of Action in the current Family Health Team

Up to 6 months 4

From 7 months to 2 years 7

From 3 years to 5 years 4

\section{Activities developed by the Family Health team members}

The interviewed people reported diverse activities that are not specific of their professions. Between the tasks they develop frequently, despite surpassing the limits of their competencies, they mentioned medications dispensations - activity included in the pharmacist nucleus of 
action - and the coordination and advising of therapeutic groups.

The professionals inserted into Basic Health Units (Unidades Básicas de Saúde - UBS) possessing in their staff other medical specialties, even when such specialties were not exclusive of the respective UBS, reported that the staff so configured was shown to be sufficient to provide the required attendance to population. Yet, the professionals inserted in Units containing in their staff only the minimum team of Family Health, indicated to have more difficulties, because the absence of other professionals generated overload and complicated the work at the referred UBS. Some of them referred the shelter as an activity professed by ESF that, in the absence of appropriate professionals, was not developed in the Unit. The pharmacist was mentioned by a nurse, as a professional that could act in the shelter activity.

About the importance of an interdisciplinary team, Meirelles (2003) refers that current reality, containing a plurality of necessities, specificities and transformations, requires different approaches with multiple theories to explain it and beard the presented problems. The health, as a dynamic and complex process, inserted in such reality, demands interdisciplinary reflections.

In this sense, it was verified that in Basic Health Units containing only the minimum team professionals, which are enabled to handle the organic aspects above all, the user generally cannot be attended in all of his necessities, because such necessities surpass the biologic conception of health, embracing all life aspects of the person looking for attendance. It is worthy to emphasize that the majority of interviewed professionals has shown an amplified conception of health, bringing preoccupations and concerns about the cultural, social, emotional, and economic context of users, and associating them to biomedical factor.

\section{Interviews Analysis}

\section{Activities attributed to pharmacist professional competence nucleus}

This category approaches the knowledge of interviewed professionals about the activities to be developed by a pharmacist. It was possible to identify that the quotations referring to pharmacist attributions were lined by representations about:

- $\quad$ the study object of the pharmacist's area - the Pharmaceutics;

- the professional practices, that is, the appropriate activities of the pharmacists' competence nucleus. The functions attributed and quoted as specific of the pharmacist professional by the minimum team of Family Health professionals were organized in the following subcategories: knowledge about medication, control and organization of pharmacy, orientation to patient, medication dispensation, technical responsibility for the pharmacy and handling of allopathic and homeopathic medications. Table II synthesizes the more frequent responses.

TABLE II - Frequency of responses related to works attributions of pharmacist professional

\begin{tabular}{lc}
\hline Sub-categories & Frequency \\
\hline Knowledge about medication: composition & $8 / 15$ \\
and pharmacological interaction & \\
Stock control/Pharmacy organization & $6 / 15$ \\
Patient orientation & $6 / 15$ \\
Medication dispensation & $5 / 15$ \\
Technical responsibility & $3 / 15$ \\
Medication handling & $2 / 15$ \\
Homeopathy & $1 / 15$ \\
\hline
\end{tabular}

As observed at Table II, the more referred responses by interviewed professionals are those recurring to medication knowledge. Then, the more quoted responses were: stock control and pharmacy organization, patient orientation, medication dispensation, technical responsibility for the pharmacy and allopathic and homeopathic medications and handling.

The attributions referred by interviewed professionals, according to Table II, are exemplified as follows:

- Knowledge about medication: to know its composition, allowing doing changes between similar and/ or generic medications, and awareness of possible interactions between medications.

“...but about the presence of pharmacist in a health team, I believe it would be interesting. Attend to this; I have a patient that is using a given drug, a given medication and...; it is from a pharmaceutical company whose name I don't know, I don't remember it; and such medication is not being effective for the patient treatment. Then, I change the substance he was using by the respective reference medication, by the original one. The patient is using the triple of the amount I would use; three times the dose I would recommend, and there is no improvement. Then, the pharmacist should participate in a team ... Even to evaluate why such medication is not functioning..." (Interview 05)

- $\quad$ Stock control: to control the amounts, input and 
output as well as validities of medications, and organize the physical space of pharmacy.

"For instance, recently, we had here the implantation of infoestoque, which is a computer program that gives a subside to known how is the unit's stock; so, we can see how complex is this situation... so..., in my opinion, the work for a pharmacist would be around this... I didn't have a more strict relationship with the pharmacist in the network..." (Interview 01)

- Orientation to patient: to orient how the patient should use the medication.

"... what more... the staff itselffeels the necessity to have a pharmacist, and many times they have difficulty to orient about medications respecting the way to take it, what's the chemical substance in the similar medication; so, the experience of a pharmacist would be very special." (Interview 04)

- Medications dispensation: to deliver the medication to patient.

"This professional we need so much. Who works in the pharmacy here? It is a nursing professional, or from any other area. Only in the great units they have a pharmacist. And we deal here with a volume of medications that you wouldn't believe... we dispense per month here, for instance, only for an antihypertensive named captopril, 40 or 50 thousand tablets per month, just to make an idea. With this number of medication, the patients eat medication, they have meals of medication." (Interview 12)

- Technical Responsibility: dispense and control psychoactive medications

“... even because this, we don't have some medications in the health posts due to the absence of a pharmacist. All the psychotropics... If a pharmacist was present over there, it would be very easy." (Interview 06)

- Handling/Homeopathy: to prepare allopathic and homeopathic medications.

"... the sensation I have is as follows: the pharmacist would work in the part of medications handling, isn't it? " (Interview 13)

In a general way, in which is referred to pharmacist attributions, it was observed that in their majority, the interviewed professionals effectively know the activities developed by the pharmacist professional. The research participants demonstrated to know the action areas of this professional, independently of previous experiences. They referred to pharmacist, as a professional whom knows me- dications, their pharmacological interactions and compositions. They reported also that is a pharmacist responsibility the stock control; as the managerial and administrative part as the psychoactive substances control. They mentioned that one of the main functions of the pharmacist is the medications dispensation linked to pharmaceutical care to user. They mentioned yet as a pharmacist attribution the preparation of allopathic and homeopathic medications.

In a work developed by Saar and Trevisan (2007) investigating the professional roles of a health team, the authors verified that the pharmacist role is clearly outlined in three areas: the management, the pharmacy and the biochemistry. They observed also that the expectation from physicians, nurses and dentists is higher respecting the pharmacist role, in which is referred to orientation and clarifications about side effects and pharmacological interactions.

The egresses from the Family Health Multiprofessional Residency have referred a more objective and detailed description about the activities developed by the pharmacist in an UBS, as well as the specific attributions inherent to such professional. As mentioned by Jodelet (1991), the individual's insertion context intervenes in the construction of representations. This construction starts from experiences, information, thinking structures received and transmitted by tradition, education and social communication. So, it is presupposed that the knowledge acquired in specialization courses in public and/or family health, summed to the different everyday experiences referring to the attributions of this professional, contributes for a construction of the pharmacist representation that is more compatible with his actual attributions and practice.

\section{Contributions and inclusion of pharmacist in the Family Health team}

When asked about the possible contributions from a pharmacist in the ESF team, the research participants mentioned the "medication" as the pharmacist's object of intervention. The pharmacist contributions in the Family Health team are associated to "pharmaceutical care" and "medications management".

Out of the 15 interviewed professionals, only 2 consider the presence of a pharmacist in the ESF team as important. Despite this, citations about possible pharmacist contributions in the team appear in 8 interviews (53.3\%). It is worthy emphasizing that in all investigated Basic Health Units there were no pharmacists. The following speech reports the contribution of pharmacist in the ESF: “... mainly like this, respecting to use of medication, the pharmacological interaction, medications interacting and so... which one is more effective; because people nowadays use 
so many medications and, sometimes, a given medication annuls the effect of other, and the pharmacist could be giving his opinion respecting this. I think it would be quite important." (Interview 09)

The participation of pharmacist professional in the Family Health Strategy, together with that from the remaining health professionals, would become more effective and ample the actions for integral attention to health. The pharmacist's contribution would be developed in several aspects: in the pharmaceutical care practice developed in the units of medication dispensation; in the composition of the professional team attending the population in the program, giving them support for an adequate intervention through information about the correct utilization of medication, besides to provide to other professionals the benefits of this practice, contributing for an improvement in the patient and community quality of life (Cunha, 2004).

The analysis of the necessity of a pharmacist inclusion in the minimum team of Family Health was characterized by the point of view of team participants and by the point of view of users, from the reports of research participants. When the interviewed professionals were asked about the way a pharmacist could act in basic attention, five suggested that a single pharmacist professional could attend two or more ESF teams or, even, to more than one UBS. It is convenient to detach that these were the professionals whom reported don't have had any contact with the pharmacist. Thus, the pharmacist would not be necessary full time in the Unit, as exemplified in this professional speech:

“... the pharmacist in our unit? I can't imagine, because it is a very small unit; we don't have not even a person to remain full time in the pharmacy, just to deliver medication. As a function of population and unit size, I think it would be appropriate to have a pharmacist per regional. I'm not sure, but apparently there are few of them in the city. So, probably, if there was a pharmacist in every regional, the northern, southern, central, eastern, mainland regions, it would be possible to have these medications controlled also per regional, in order to avoid the necessity of a person to leave his own neighborhood, going to downtown seeking a medication." (Interview 10)

The speeches presenting this type of representation, that is, the pharmacist as an advisor for subjects involving medications and his regular presence being not necessary, reflect the historic context of a pharmaceutical practice characterized mainly by a professional identity crisis, generating a lack of social recognition and little insertion in basic attention activities. It is appropriate to emphasize yet the characteristic of current pharmaceutical formation, which is excessively technical and with just incipient formation in the clinical area (OPAS, 2002), not emphasizing the perspective of health systems. Besides, the few professionals working with basic attention, effectively, face a work routine that hampers any actions related to Pharmaceutical Care practice: the resolution of operational problems referring to stock management and the attendance to a growing demand of users, centered in issues strictly related to medical prescription. Such activities limit a larger involvement of the professional with the health team, beyond to embarrass activities such as the implantation of pharmaceutical care service centered in the pharmacotherapeutic follow-up, looking for an improvement in patient's adherence to prescribed treatment and the prevention of possible problems related to medications (Araújo et al., 2008).

The remaining professionals (ten) have manifested the necessity of a pharmacist, being that two of them mentioned the day to day presence of a pharmacist as a team member, and the remaining ones (eight) referred it as important for the UBS. The following report approaches the topic of professional's specific formation, his professional contact with others in the health area and the perception of a necessity of other knowledge areas:

"I think that the minimal team should have all of these residency professionals, so, besides the physician, a nurse, a dentist..." (Interview 04)

In which is referred to activities attributed to pharmacist, and developed by members of the minimal team of Family Health, many professionals report that as there is no pharmacist neither at UBS, nor in the team, everybody involved in the Unit work develop such activities. In other words, the activities are done by any immediately available professional within the Basic Health Unit, irrespective his original function as an officer, nurse or nursing assistant.

“... I think important a pharmacist herein, in a sector that nursing cares, the pharmacy; I don't like to work over there. I don't few us, nurses, apt to stay over there". (Interview 08)

When asked about the discussions and actions developed for inclusion of other professionals in the health team, the response was almost unanimous: there is no formal discussion respecting this subject, not even actions to enable the hiring of professionals. The reasons vary from the disbelief in government investment, up to the need for more employees of technical and higher level, of those professions already inserted in the minimum team of Family Health. 
Considering that the health care professional formation is based on biomedical science, this professional tends to ignore and even depreciate the knowledge and practice of other wisdom areas, restricting so the discussion around the specificities of every category, a fact that, by its time, complicates the global comprehension of the disease-health process. Everybody lose in this process: as the professional whom does not share his knowledge, as the professional whom does not understand the importance of his colleague. Obviously, the UBS user is the main affected for such situation (Gomes, 1997).

When asked about the users point of view, the interviewed professionals answered that, generally, the users do not request for other professionals. Ultimately, the interviewed professionals recognize the importance of other professional categories and their necessity within Basic Health Units, but little is done to inform the user, the health team and general population about the subject. An interviewed professional has mentioned the absence of requests for other professionals from the part of users, due to their ignorance about the importance of these additional professionals:

"I think that it depends on our own awareness about this importance; we should demonstrate it to general population; it would be better for their health; then, they would reclaim to government for other professionals hiring and inclusion in the basic team. I believe this is the beginning; if we know the importance, the general population need to feel such importance to claim for this right, for their inclusion in the PSF* teams." (Interview 04)

*PSF = Programa de Saúde da Família or Family Health Program

For Gomes (1997), it is significant the difference between the expectations, values and parlance of health professionals and population, which brings great communication difficulties between them. The author herself proposes a solution for the impasse: the communitarian participation, that is, the population should participate of all steps of health activities, from the planning and operation, up to processes evaluation.

In such a way, the inclusion of other professionals in the Family Health teams depends, mainly, on the educative actions from the already inserted professionals, whom should demonstrate to population the necessity of other professional categories for an integral attendance. Many times, the user knows about his necessity, but does not identify or ignore the professional that could better attend him. He looks for professionals that are accessible to him at UBS, and his objective is to have his problem resolved, immediately, even if temporarily. If the physician, the nurse or the dentist tries to attend a necessity that is beyond his competence nucleus, being it emotional, alimentary, social or other, the user could feel himself satisfied; however, he does not dispose of information respecting the existence of other professionals able to attend such necessity, whom certainly could offer a more adequate and effective assistance to his demand. In this sense, it was clear in several interviews that the professionals of Family Health team "cap the holes" of lacking of other professionals, avoiding so the demand appearance.

Thus, the conceptions and representations that the professionals already inserted in the minimum team construct and adopt respecting the remaining professionals, imply directly in their practices and relationships that in the future they will develop with these latter professionals, from their insertion in the basic attention. It represents for the health professionals, and also for the society as a whole, tools for reflection and reconstruction of symbols, ideas and applications, interfering in the practice of integral assistance to health.

\section{Sources of information about the pharmacist action}

The studies of social representations privilege the information sources, that is, the access to knowledge that originated a given representation. So, they are constitutive of the representational object.

When asked about the information source that originated their representations about the pharmacist, the interviewed professionals mentioned the following ones: professional experience, personal experience and media.

Professional experience: is the information obtained by means of formal relationships, direct contact with professionals during the formation (graduation, qualification and extension courses, post-graduation), with work colleagues (in the public or private service) or as users of this type of services.

Personal experience: it is the information obtained by means of informal relationship of friendship or kinship, through direct contact with these professionals, currently or not.

Media: it includes information obtained by access to written materials (scientific articles, magazines and books) and internet.

It is convenient to emphasize the influence of the following aspects on the knowledge of interviewed professionals about the contributions of this referred professional, and even on the actual necessity of his action at ESF:

In the professional and personal experiences, their positive evaluation was associated to a higher knowledge and the reference to necessity of inclusion of 
such professionals; while their negative evaluation was associated to doubts about their action and implied in the indication that they are not necessary at ESF.

In the professional experiences at Basic Health Units that count on amplified teams, the participation of professionals was evaluated as important for the interchange of wisdoms, the apprenticeship and the amplification of diverse areas of knowledge.

\section{FINAL CONSIDERATIONS}

The research investigated the social representations from professionals of the minimum team of Family Health about the action of a pharmacist professional. To contextualize these representations, it was necessary to understand the participants conceptions about the integrality of basic attention to health, nucleus of competence and existence of difficulties or limitations in the actions of ESF, as a result of current composition of minimum team.

It was verified that these representations were constructed on the base of following parameters: a) object of study and intervention of this professional's field; $b$ ) the practices related to his nucleus of competence; and c) his action in specific cases. One of the relevant factors for such construction was the evaluation of participants' previous experiences with the pharmacist, and of the obtainment of information by means of professional or personal contact and media. For instance, when the interviewed professionals didn't have previous experiences with the pharmacist professional, his participation in the team was not considered as necessary.

Respecting to activities of the pharmacist's nucleus of competence, the interviewed professionals have mentioned that in some situations, they develop functions pertinent to these nuclei. It was also referred that users, usually, do not demand the attendance, due to ignorance about the possible pharmacist's contributions. So, the inclusion of other professionals in the teams of Family Health would depend, mainly, on educative actions from the already inserted professionals. They would demonstrate to population the need of other professions for an integral attendance.

Integrality supposes sharing of wisdoms in the day to day practice, but it does not include the substitution of other professionals, because this substitution implies in private the users of their attention in all of their necessities and subjectivity dimensions, in a resolutive manner.

It is important to detach that the possibilities of pharmacist's contribution at ESF, were many, mentioned by the interviewed professionals. Besides, many difficul- ties in the work process were related to limitations in the nucleus of competence, and the interviewed professionals reported several characteristics of the presented demand, which would be better attended if a multiprofessional and interdisciplinary team was present. However, there is a contradiction related to this aspect, because part of participants evaluated as satisfactory the existence of a professional for the attendance of three to five teams, as a reference and not as an effective member of ESF team. This comprehension is in accordance with Ordinance 1065 of 2005 July, published by the Ministry of Health, proposing the creation of Nuclei of Integral Attention in Family Health (Brasil, 2005). It is necessary, however, to emphasize that the referred Ordinance maintains the professionals as specialists, and not as necessary staff for the basic attention, and such proportion of professionals for the number of teams will not assure the population access to services, harming so their quality. This organization will not favor the link between health professionals and respective population, one of the basic requisites for the good functioning of ESF.

Anyway, with the establishment of funding blocks through Ordinance 698/06, between these blocks those of basic attention and pharmaceutical care, a cycle identified by the meeting between the pharmacist and the health and social necessities of Brazilian population was inaugurated, within the public sector, with federal resources for the defrayal of resulting actions (Santos, 2006). It is expected a change in the current status of pharmacist profession, passing to be emphasized the pharmaceutical services associated to medication, its rational use and, mainly, to patient. It is considered yet the necessity of amplifying the discussions about the pharmacist interaction with remaining professionals, in the Unified Health System (Sistema Único de Saúde - SUS).

\section{REFERENCES}

ARAÚJO, A.L.A.; PEREIRA, L.R.L.; UETA, J.M.; FREITAS, O. Perfil da assistência farmacêutica na atenção primária do Sistema Único de Saúde. Ciênc. Saúde Col., v.13, Supl.?, p.611-617, 2008.

BARDIN, L. Análise de conteúdo. Lisboa: Edições 70, 1977. $225 \mathrm{p}$.

BRASIL. Ministério da Saúde. Gabinete do Ministro. Portaria $n^{o}$ 1065/GM de 4 de julho de 2005. Cria os Núcleos de Atenção Integral na Saúde da Família, com a finalidade de ampliar a integralidade e a resolubilidade da Atenção à Saúde. Available at: http://dtr2001.saude.gov.br/sas/ PORTARIAS/Port2005/GM/GM-1065.htm. Accessed on: 3 set. 2007. 
BRASIL. Ministério da Saúde. Gabinete do Ministro. Portaria $n^{\circ}$ 648/GM de 28 de março de 2006. Aprova a Política Nacional de Atenção Básica, estabelecendo a revisão de diretrizes e normas para a organização da Atenção Básica para o Programa Saúde da Família (PSF) e o Programa Agentes Comunitários de Saúde (PACS). Available at: http:/dtr2001.saude.gov.br/sas/PORTARIAS/Port2006/ GM/GM-648.htm. Accessed on: 13 jun. 2008.

BRASIL. Ministério da Saúde. Gabinete do Ministro. Portaria $n^{\circ}$ 698/GM de 30 de março de 2006. Define que o custeio das ações de saúde é de responsabilidade das três esferas de gestão do SUS, observado o disposto na Constituição Federal e na Lei Orgânica do SUS. Available at: http:// dtr2001.saude.gov.br/sas/PORTARIAS/Port2006/GM/ GM-698.htm. Accessed on: 14 set. 2007.

BRASIL. Ministério da Saúde. Secretaria de Assistência à Saúde. Coordenação de Saúde da Comunidade. Uma estratégia para a reorientação do modelo assistencial. Brasília: Ministério da Saúde, 1997. 37 p.

BRASIL. Ministério da Saúde. Secretaria de Políticas de Saúde. Departamento da Atenção Básica. Cadernos de Atenção Básica. Estratégia Saúde da Família. Implantação de uma Unidade de Saúde da Família. Brasília: Ministério da Saúde, 2000. 44 p.

BRASIL. Ministério da Saúde. Secretaria de Políticas de Saúde. Departamento de Atenção Básica. Manual para a organização da Atenção Básica. Brasília: Ministério da Saúde, 2001. 40 p.

CAMPOS, C.E.A. O desafio da integralidade segundo as perspectivas da vigilância da saúde e da saúde da família. Ciênc. Saúde Col., v.8, n.2, p.569-584, 2003.

CUNHA, M.C. Agora, sim, o Farmacêutico vai integrar o PSF. Pharm. Bras., n.44, p.4-5, 2004.

DA ROS, M.A.; CORSO, A.; CARCERERI, D.; HEIDEMANN, I.; GONÇALVES, J.; CREPALDI, M.A.; SISSON, M.; VERDI, M.; MACHADO, N.V.; RECH, N.; MIOTO, R.; SANTOS, R.; NITSCHKE, R. Projeto de implementação do curso de Especialização em Saúde da Família: Modalidade Residência. Florianópolis, 2002. 85 f. anexo 10. [Pós Graduação Lato Sensu-Especialização em Saúde da Família/Modalidade Residência. Projeto-Universidade Federal de Santa Catarina].
DALLA COSTA, E.M.O. O enfoque familiar na formação dos profissionais farmacêuticos. Olho Mágico, v.6, p.16-18, 2000.

GOMES, D.C.R. (Org.). Interdisciplinaridade em saúde: um princípio a ser resgatado. In: Equipe de saúde: o desafio da integração. Uberlândia: Editora da Universidade Federal de Uberlândia, 1997. p. 19-41.

JODELET, D. Representation Sociale. In: Grand dictionnaire de la psychologie. Paris: Larousse, 1991. p.668-672.

MEIRELLES, B.H.S. Viver saudável em tempos de AIDS: a complexidade e a interdisciplinaridade no contexto de prevenção da infecção pelo HIV. 2003. Florianópolis, 2003. 130 f. [Tese de Doutorado em Enfermagem. Universidade Federal de Santa Catarina].

MINAYO, M.C.; SANCHES, O. Quantitativo-qualitativo: oposição ou complementariedade? Cad. Saúde Pública, v.9, n.3, p.39-262, 1993.

ORGANIZAÇÃO PAN-AMERICANA DA SAÚDE. Atenção Farmacêutica no Brasil: trilhando caminhos. Relatório 2001-2002. Brasília, 2002. 46p. Available at: http://www.opas.org.br/medicamentos/site/UploadArq/ RelatorioAtenfar20012002.pdf Accessed on: 25 nov. 2007.

SAAR, S.R.C.; TREVIZAN, M.A. Papéis profissionais de uma equipe de saúde: visão de seus integrantes. Rev. Lat.-Am. Enferm., v.15, n.1, p.106-112, 2007.

SANTOS, J.S.S. Atenção básica abre novo ciclo ao farmacêutico. Pharm. Bras., n.52, p.3, 2006.

SILVA, I.Z.Q.J.; TRAD, L.A.B. O trabalho em equipe no PSF: investigando a articulação técnica e a interação entre os profissionais. Interface Comun. Saúde Educ., v.9, n.16, p.25-38, 2004/2005.

VIEIRA, F.S. Possibilidades de contribuição do farmacêutico para a promoção da saúde. Ciênc. Saúde Col., v.12, n.1, p.213-220, 2007.

Received for publication on $31^{\text {th }}$ march 2008 Accepted for publication on $07^{\text {th }}$ november 2008 